\title{
REVITALISASI EMPING MELINJO DAN SATE BANDENG BERBASIS LOCAL FOOD DIVERSIFICATION GUNA MENINGKATKAN PEREKONOMIAN MASYARAKAT BANTEN
}

\author{
Ranthy Pancasasti ${ }^{1}$, Natiqah $^{2}$, Ana Susi Mulyani ${ }^{3}$, Elmie Hanafi ${ }^{4}$ \\ ${ }^{1,2,3}$ Universitas Sultan Ageng Tirtayasa, Jl Kampus Terpadu Sindang Sari, Pabuaran, Serang, Banten, Indonesia \\ Email: ranthyipb@gmail.com
}

\begin{abstract}
Banten Province has a variety of regional specialties, including Sate Bandeng and Emping Melinjo. But now, the typical Banten food is starting to get a little bit of interest. Therefore, the PPM team created a program based on Local Food Diversification for Banten specialties. The method/approach used is participatory, starting from planning, implementation to evaluation, for example through seminars, workshops, field meetings, coaching as well as through printed information media and IT-based electronic media. The results of this PPM are in the form of a documentary on the YouTube Channel and content on social media about Emping Melinjo and Sate Bandeng, in order to participate in assisting government programs, promoting Emping Melinjo and Sate Bandeng to remain sustainable and known to foreign countries.
\end{abstract}

Keywords: Melinjo Emping; Milkfish Satay; Local Food Diversification.

\begin{abstract}
ABSTRAK
Provinsi Banten memiliki keanekaragaman makanan khas daerah, diantaranya Sate Bandeng dan Emping Melinjo. Namun saat ini, makanan khas Banten tersebut mulai sedikit peminatnya. Oleh sebab itu, tim PPM membuat suatu program yang berbasis Lokal Food Diversification untuk melestarikan makanan khas Banten. Metodelpendekatan yang digunakan adalah partisipatif, mulai dari perencanaan, pelaksanaan sampai dengan evaluasi, misalnya melalui seminar, workshop, temu lapang, pembinaan serta melalui media informasi tercetak dan media elektronik berbasis IT. Hasil PPM ini berupa film dokumenter di YouTube Channel dan konten di social media tentang Emping Melinjo dan Sate Bandeng, dalam rangka ikut serta membantu program pemerintah, mempromosikan Emping Melinjo dan Sate Bandeng agar tetap lestari dan dikenal sampai ke manca negara.
\end{abstract}

Kata Kunci: Emping Melinjo; Sate Bandeng; Diversifikasi Makanan Lokal.

\section{PENDAHULUAN}

Menurut data dari laman online Biro Pemerintahan Provinsi Banten, Kota Serang adalah wilayah baru hasil pemekaran, Kabupaten Serang Provinsi Banten. Sebagai ibukota dari sebuah provinsi, kehadirannya adalah sebuah konsekuensi logis dari keberadaan Provinsi Banten. Kota Serang memiliki luas wilayah 266,77 km dengan jumlah penduduk sekitar 672,833 jiwa dan Batas wilayah. Dari 6 kecamatan tersebut terdiri dari 20 Kelurahan dan 46 Desa. Kota Serang 
diresmikan pada tanggal 2 November 2007 berdasarkan UU Nomor 32 Tahun 2007 tentang Pembentukan Kota Serang, setelah sebelumnya RUU Kota Serang disahkan pada 17 Juli 2007 kemudian dimasukan dalam lembaran Negara Nomor 98 Tahun 2007 dan tambahan lembaran Negara Nomor 4748, tertanggal 10 Agustus 2007. Taktakan merupakan sebuah kecamatan di Kota Serang, Provinsi Banten, Indonesia. Taktakan terletak di sebelah barat daya Kota Serang. Taktakan memiliki 13 desa/kelurahan. Kecamatan Taktakan merupakan wilayah yang memiliki hasil perkebunan dan hasil hutan yang lebih dominan daripada kecamatan-kecamatan yang lain, hal ini karena taktakan daerah pegunungan. Hasil hutan yang paling terkenal dari daerah Taktakan yaitu durian, melinjo, cengkih dan ubi-ubian yang lain. Namun, yang mendominasi dari kesemuanya itu yaitu melinjo yang biasa dibuat emping yang menjadi makanan khas Banten. Melinjo menjadi tanaman utama di kawasan taktakan. Salah satu industri Emping Melinjo yang berada di wilayah Taktakan adalah Home Industry Bapak Jawiulloh yang berada di Desa Kubang, Kelurahan Cilowong, Kecamatan Taktakan, Kota Serang Provinsi Banten. Di sisi lain, Kecamatan Serang secara administrasi terdiri dari 12 kelurahan, 189 rukun warga dan sebanyak 771 rukun tetangga. Agroindustri sate bandeng banyak terdapat di Kecamatan Serang yang dikelola dalam industri skala kecil. Salah satunya adalah Sate Bandeng Ibu Aliyah yang bertempat di Jalan Lopang Gede, Kelurahan Lopang, Kecamatan Serang, Kota Serang, Provinsi Banten. Berdasarkan hal tersebut, maka perlu adanya upaya untuk mengelola dan memanfaatkan Emping Melinjo dan Sate Bandeng untuk menjadi produk unggulan yang bernilai ekonomi, ekologi, sosial dan budaya masyarakat, serta menjadi sumber pendapatan bagi masyarakat, sehingga dapat memicu tumbuhnya home industry (Usaha Kecil dan Menengah - UKM)

\section{Kondisi Mitra}

Dalam kondisi saat ini, makanan khas lokal daerah mulai sedikit peminatnya, karna tergeser oleh makanan modern yang rata-rata berasal dari luar negeri, maka dari itu untuk melestarikan makanan khas lokal Tim PPM membuat suatu program yang berbasis Lokal Food Diversification. Metode/pendekatan yang akan digunakan agar upaya untuk mengelola Emping Melinjo dan Sate Bandeng menjadi produk unggulan dapat sampai ke pengguna/masyarakat secara cepat dan tepat sasaran sehingga terjadi peningkatan kemampuan dan keterampilan masyarakat adalah partisipatif, mulai dari perencanaan, pelaksanaan sampai dengan evaluasi, yang dilakukan secara langsung maupun tidak langsung, misalnya melalui seminar, workshop, temu lapang, pembina an pemilik home industry Emping Melinjo dan Sate Bandeng serta melalui informasi media cetak dan media elektronik. 


\section{Permasalahan Prioritas Mitra}

1. Belum adanya teknik pengelompokkan jenis Emping Melinjo.

2. Belum adanya teknik agar rasa Emping Melinjo tidak terlalu pahit.

3. Belum adanya diversifikasi Emping Melinjo menjadi aneka produk seperti: Emping Melinjo karamel, emping cookies, stik Emping Melinjo, keripik kulit melinjo.

4. Belum terwujudnya pelaku usaha home industry Emping Melinjo yang mandiri berbasis agribisnis dan berdaya saing.

5. Belum adanya teknik Sate Bandeng tanpa duri.

6. Belum adanya strategi pengemasan Sate Bandeng yang tahan lama saat dipasarkan secara konvensional maupun online.

7. Belum terwujudnya pembangunan ekonomi masyarakat dengan mendiversifikasi Sate Bandeng menjadi aneka produk seperti: daging burger, otak-otak, nugget dan perkedel.

8. Belum terwujudnya jiwa kepemimpinan pemilik usaha Sate Bandeng agar kuliner Sate Bandeng lebih dikenal masyarakat luar.

9. Belum adanya pemasaran Emping Melinjo dan Sate Bandeng yang berbasis Digital Marketing.

\section{METODE}

\section{Tahapan Atau Langkah-Langkah Dalam Melaksanakan Solusi Dari Permasalahan Mitra}

Tahapan atau langkah-langkah dalam melaksanakan solusi dari permasalahan mitra untuk mendukung realisasi tujuan, tim pengusul program melakukan serangkaian tahapan dalam melaksanakan solusi dari permasalahan mitra sebagai berikut:

1. Menciptakan teknik untuk mengelompokkan Emping Melinjo gunanya agar terlihat kualitas dari Emping Melinjo dengan cara setelah Emping Melinjo sudah selesai pada tahap penyangraian maka langkah selanjutnya yaitu menyortir ukuran dari Emping Melinjo. Dengan cara dibedakan menurut ukurannya maka akan diketahui jenis Emping Melinjo mana yang banyak (terlihat tebal) maupun yang sedikit (terlihat tipis) menggunakan bahan utama yaitu melinjo.

2. Menciptakan teknik untuk mengolah Emping Melinjo agar rasanya tidak terlalu pahit yaitu dengan cara saat ingin menggoreng Emping Melinjo harus dalam kondisi yang kering, serta saat menggorengnya ditambahkan mentega. Karena dengan menambahkan mentega bisa menyamarkan rasa pahit di Emping Melinjo

3. Membuat berbagai aneka produk makanan olahan seperti: Emping Melinjo karamel, emping cookies, stik Emping Melinjo, keripik kulit melinjo. Yang merupakan macam produk 
diversifikasi dari Emping Melinjo. Tujuan nya untuk membuat aneka ragam piliihan tidak hanya Emping Melinjo saja yang diproduksi.

4. Mewujudnya para pelaku usaha home industry Emping Melinjo yang mandiri berbasis agribisnis dan berdaya saing dengan cara partisipatif bersama masyarakat, mulai dari perencanaan, pelaksanaan sampai dengan evaluasi, yang dilakukan secara langsung maupun tidak langsung, yaitu melalui seminar, workshop, temu usaha, temu lapang (seperti penyuluhan secara berkelanjutan tentang manfaat dari emping yang merupakan bahan dasar melinjo), serta melalui media informasi tercetak (jurnal, leaflet) dan media elektronik (internet).

5. Menciptakan strategi pengemasan dengan teknik mengemas sate bandeng dengan pengemasan vakum. Vacuum Packing adalah alat yang digunakan untuk mempacking makanan dengan cara menghampakan udara yang ada di dalamnya. Dengan cara kerja seperti ini menjadikan Sate Bandeng bisa disimpan lebih lama sehingga bisa dipasarkan secara konvensional maupun online tanpa khawatir Sate Bandeng akan membasi

6. Membuat aneka produk makanan olahan seperti: daging burger, otak-otak, nugget dan perkedel. Yang merupakan produk-produk diversifikasi dari Sate Bandeng. Tujuannya untuk membuat aneka ragam piliihan tidak hanya Sate Bandeng saja yang diproduksi.

7. Mewujudkan jiwa kepemimpinan seorang pemilik usaha Sate Bandeng agar Sate Bandeng lebih dikenal masyarakat luar, dengan cara berupa dengan menyelenggarakan pelatihan kepemimpinan guna memberikan sebuah wawasan bahwa kuliner Sate Bandeng memiliki potensi yang amat besar untuk dijadikan sumber pendapatan bagi masyarakat

8. Memperkenalkan digital marketing yang mana sebagai media pemasaran Sate Bandeng dengan cara: pemilik home industry Emping Melinjo dan Sate Bandeng mengikuti pelatihan untuk bisa memasarkan Sate Bandeng melalui media sosial dan e-commerce seperti Instagram, Facebook, Tiktok, Shopee dan Lazada.

\section{Metode Pendekatan yang Ditawarkan Untuk Menyelesaikan Persoalan Mitra}

Pengabdian kepada masyarakat ini memiliki fokus memberikan ketrampilan dan wawasan wirausaha kepada anggota tim PPM dalam rangka meningkatkan pendapatan keluarga mereka dan secara tidak langsung meningkatkan kesejahteraan keluarganya. Metode yang digunakan dalam kegiatan ini adalah sebagai berikut:

1. Metode memilah yaitu dengan mengelompokkan jenis dan ukuran Emping Melinjo yang nantinya akan dipasarkan.

2. Metode penggorengan Emping Melinjo dengan memastikan jenis margarin yang dipakai berkualitas karena akan membuat rasa emping gurih dan tidak terlalu pahit serta memastikan 
Emping Melinjo dalam kondisi kering sebelum digoreng agar emping mekar dengan sempurna dan super renyah

3. Metode/pendekatan yang digunakan adalah partisipatif, mulai dari perencanaan, pelaksanaan sampai dengan evaluasi, yaitu bersama masyarakat memasak/membuat aneka produk makanan dari Emping Melinjo seperti: Emping Melinjo karamel, emping cookies, stik Emping Melinjo, keripik kulit melinjo

4. Metode/pendekatan yang digunakan adalah partisipatif, dengan cara memotivasi dan menumbuhkan jiwa entrepreneur masyarakat sebagai pengusaha (UMKM) home industry makanan Emping Melinjo dengan tetap memperhatikan aspek kesehatan, ekologi, ekonoi, dan budaya masyarakat.

5. Metode penghalusan daging ikan bandeng menggunakan saringan strainless steel yang mempunyai kawat rapat teknik ini bisa menguraikan daging ikan bandeng sehingga duri ikan terlihat dan bisa langsung dihilangkan. Selanjut nya yaitu menyangrai daging ikan bandeng sebentar, gunanya untuk mengurai duri yang masih tersisa.

6. Metode/pendekatan yang digunakan adalah partisipatif, mulai dari perencanaan, pelaksanaan sampai dengan evaluasi, yang dilakukan secara langsung maupun tidak langsung, dengan cara melakukan inovasi dalam penggunaan jenis kemasan yang lain dengan menggunaan kemasan vacuum sealer, melakukan inovasi dalam penyimpanan pada suhu dingin sehingga memperpanjang masa simpan serta menggunakan teknik Vacuum Packing.

7. Metode/pendekatan yang digunakan adalah partisipatif, mulai dari perencanaan, pelaksanaan sampai dengan evaluasi, yaitu bersama masyarakat memasak/membuat aneka produk makanan dari olahan sate bandeng seperti: daging burger bandeng, otak-otak, nugget dan perkedel

8. Metode/pendekatan yang digunakan adalah partisipatif, mulai dari perencanaan, pelaksanaan sampai dengan evaluasi, yang dilakukan secara langsung maupun tidak langsung, yaitu dengan memotivasi para pemilik usaha untuk mendirikan usaha kecil menengah (UKM) yang dapat berdaya saing, memberikan pelatihan manajemen bisnis UKM, dan melakukan kerjasama dengan koperasi/perusahaan yang dapat memberikan modal kepada pemiliki UKM sate bandeng.

9. Metode/pendekatan yang digunakan adalah Metode Focus Group Discussion (FGD) dan SWOT Analysis dengan cara: (a) mengadakan seminar untuk pelaku usaha home industry Emping Melinjo dan Sate Bandeng tentang pemasaran produk berbasis digital marketing (b) memberi pelatihan kepada pelaku usaha home industry untuk bisa memasarkan emping melinjo dan sate bandeng melalui media social dan e-commerce seperti instagram, facebook, tiktok, shopee, lazada. 


\section{HASIL DAN PEMBAHASAN}

\section{Pelaksanaan Program PPM}

\section{a) Emping Melinjo}

\section{Sebelum Dilaksanakannya Program PPM}

\section{Cara membuat emping melinjo}

\section{Bahan-Bahan:}

- Melinjo

\section{Cara Pembuatan:}

1. Biji melinjo disortir, Biji Melinjo (buah Melinjo yang telah dikuliti) disangrai (digoreng tanpa menggunakan minyak goreng) sedikit demi sedikit di atas penggorengan.

2. Jika sudah matang, Melinjo yang sudah disangrai lalu diangkat lalu dikupas kulitnya dengan cara digerus di atas Layah / penggerusan yang lebar.

3. Satu - persatu Melinjo ditaruh di landasan/ Talenan lalu digeprek (dipipihkan) dengan batu sampai Melinjo menjadi pipih dan bundar tipis (untuk ukuran standar)

4. Emping yang menempel di landasan sesudah digeprek / ditumbuk menjadi pipih, diangkat dari Talenan dengan menggunakan Lading atau Skrap

5. Setelah terbentuk emping, dalam kondisi basah, Emping ditata di atas Widik (wadah serupa geribik) untuk dijemur hingga kering. Proses pengeringan dibutuhkan waktu kirakira dua sampai tiga jam.

6. Apabila telah kering, Emping diangkat dimasukan keranjang dan siap dipasarkan

\section{Setelah Dilaksanakannya Program PPM}

\section{Emping Cookies}

Emping Cookies Merupakan olahan camilan emping melinjo dengan perpaduan berbagai rasa manis, memiliki tekstur renyah garing dan rasanya gurih dan berpadu manis.

\section{Bahan-Bahan:}

- 50 gram Hollman Butter

- 50 gram Margarin

- 1sdt garam

- 1 sdt Rexa vanila

- 2 kuning telur, dan 1putih telur

- 200 gram Emping dihaluskan

- 50 gram kacang tanah sangria 


\section{Cara Pembuatan:}

1. Kocok butter, margarin, roomboter, rexa cookies, garam dan rexa vanili hingga putih dan mengembang.

2. Masukkan telur, kocok hingga rata. Tambahan emping dan kacang, aduk rata. Matikan mikser.

3. Masukkan campuran terigu, aduk hingga rata. Simpan adonan selama 15 menit dalam lemari es.

4. Keluarkan adonan, giling hingga setebal $3 \mathrm{~mm}$. Potong-potong dengan cookie cutter sesuai selera.

5. Taruh di loyang datar, beri bahan olesan lalu taburi wijen hitam dan putih. Panggang dalam oven panas $150 \mathrm{C}$ selama 30 menit. Angkat dan dinginkan.

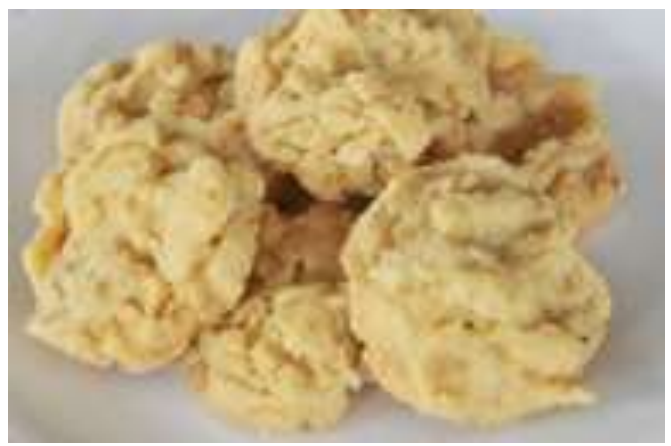

Gambar 1. Emping Cookies

\section{Emping Melinjo Karamel}

Emping melinjo karamel sudah berupa olahan emping melinjo matang sehingga tak perlu digoreng lagi. Emping melinjo karamel dibuat dengan tambahan gula sebagai pemanis atau semacam karamel. Emping melinjo karamel ini, rasa manis dari gula asli.

\section{Bahan-Bahan:}

- 500 gram Emping Melinjo Goreng

- 150 gram margarin

- 150 gram gula palm

- 75 gram gula pasir

\section{Cara Pembuatan:}

1. Dengan sangat kecil, panaskan gula palm, gula pasir, dan margarin, aduk perlahan sampai meleleh dan tercampur rata 
2. Tambahkan baking soda dan garam, aduk cepat sampai tercampur rata dan menguap, matikan kompornya.

3. Masukan Emping Melinjo yang suda digoreng, lalu aduk rata dan angkat.

4. Pindahkan kewadah saji, angin-anginkan sampai dingin, emping karamel sudah siap.

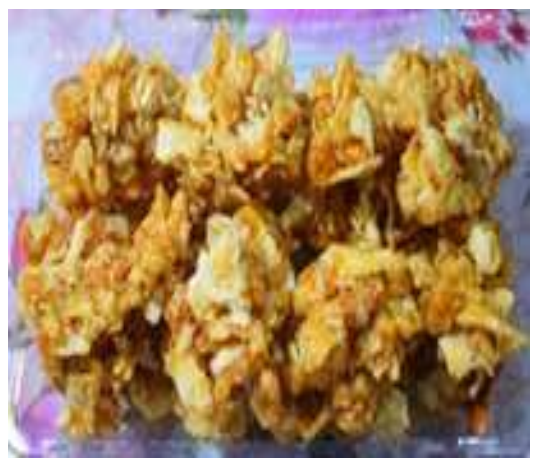

\section{Gambar 2. Emping Melinjo Karamel}

\section{Stik Emping Melinjo}

Pengolahan buah melinjo hingga menjadi Stik Emping Melinjo meliputi pembuangan kulit, pembuangan kulit keras dan kulit ari dengan cara disangrai (digoreng tanpa minyak), pemberian bumbu, pengukusan, penggilingan, pengirisan, berbentuk stick, pengeringan, dan penggorengan. Stik Emping Melinjo yang masih mentah berwarna putih kekuning - kuningan dan berbentuk pipih panjang seperti stick sehingga disebut Stik Emping Melinjo.

\section{Bahan-Bahan:}

- Buah Melinjo

- Pasir

- 500 gr tepung terigu

- 1 sdt baking powder

- $1 / 2$ sdt garam

- secukupnya kaldu bubuk

- secukupnya daun bawang seledri (iris tipis)

- $200 \mathrm{ml}$ air

- 2 sdm margarin

- 3 sdm minyak sayur

- secukupnya minyak sayur untuk menggoreng

\section{Cara Pembuatan:}

1. Persiapan bahan Buah melinjo dikupas kulit luarnya dengan pisau sehingga diperoleh buah melinjo berupa klathak (buah melinjo tanpa kulit luar). Kemudian, buah melinjo 
berupa klathak tersebut digoreng sangan (digoreng tanpa minyak) dengan pasir atau tanpa pasir.

2. Pengukusan, mengukus daging buah melinjo dimasukan ke dalam soblok atau kukusan. ditambah bumbu yang diinginkan sambil diaduk - aduk hingga merata, misalnya cabai (rasa pedas), bawang putih (rasa gurih), gula pasir (rasa manis), diaduk sampai rata dan siap digiling.

3. Pembentukan stick Adonan emping yang telah berbumbu sedikit demi sedikit dimasukan dalam mollen dengan ketebalan tertentu sehingga menghasilkan lempengan panjang.

4. Pengeringan Emping stick melinjo yang masih mentah hingga setengah kering. Selanjutnya, emping stick melinjo mentah yang sudah setengah kering tersebut dijemur pada panas matahari hingga kering dan dilakukan selama 1 hari bila matahari bersinar penuh.

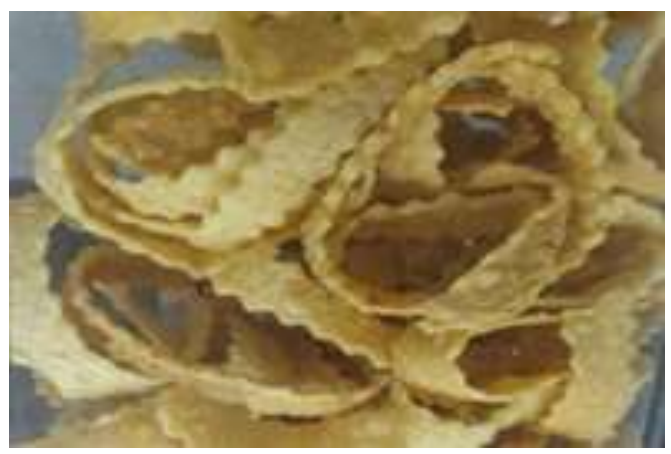

Gambar 3. Stik Emping Melinjo

b) Sate Bandeng

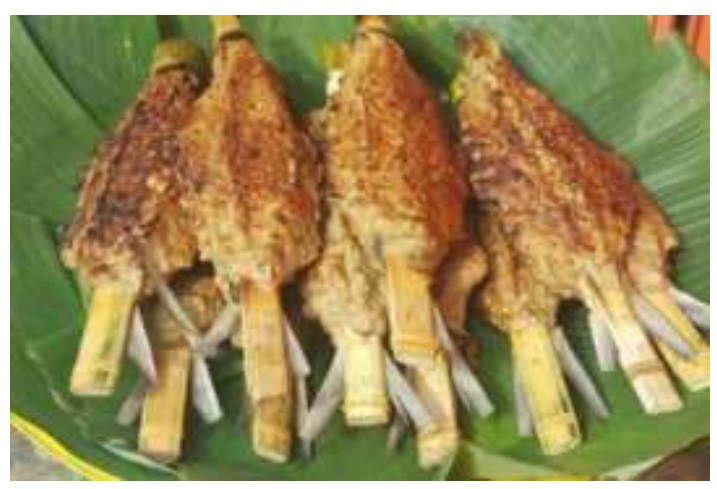

Gambar 4. Sate Bandeng Sebelum Dilaksanakannya Program PPM 
Sate Bandeng adalah masakan tradisional khas Banten, Indonesia. Sate Bandeng dibuat dari ikan bandeng yang dihilangkan durinya, dagingnya dibumbui dan dimasukkan kembali ke kulitnya, lalu ditusuk atau dijepit tusukan tangkai bambu, lalu dibakar di atas bara arang.

Bahan-bahan:

- $\quad 2$ sdm minyak

- 1 ekor ikan bandeng ukuran besar

- 100 g kelapa parut kasar, sangrai

- $\quad 1 \frac{1}{2}$ sdt garam

- $\quad 1 / 2$ sdt gula pasir

- $\quad 1 / 2$ sdt asam jawa, larutkan dengan $1 / 2$ sdm air panas

- 2 butir telur ayam

- $100 \mathrm{ml}$ santan cair

- Daun pisang, untuk membungkus

- bambu, untuk penjepit

- 3 buah cabai merah besar

- 12 butir bawang merah

- $\quad 5$ siung bawang putih

- $\quad 1 \frac{1}{2}$ sdt ketumbar

- $\quad 1 / 4$ sdt jinten

- $2 \mathrm{~cm}$ jahe

- $\quad 1 \mathrm{~cm}$ lengkuas

- $3 \mathrm{~cm}$ kunyit bakar

\section{Cara Pembuatan:}

1. Keruk daging ikan bandeng.

2. Sangrai daging ikan hingga kering. Angkat. Pisahkan durinya, bila ada.

3. Panaskan minyak, tumis bumbu halus hingga harum.

4. Tambahkan daging bandeng, kelapa sangrai, garam, gula pasir, dan air asam, aduk hingga rata. Angkat, pindahkan ke dalam mangkuk dan biarkan hingga dingin.

5. Tambahkan telur dan santan, aduk hingga rata.

6. Ambil $1 / 3$ bahan adonan, sisihkan sisa adonan. Masukkan $1 / 3$ bahan ke dalam kulit bandeng.

7. Bentuk kembali hingga menyerupai ikan utuh.

8. Jepit ikan dengan bilah bambu, sisihkan.

9. Bentangkan dua lembar daun pisang, taruh $1 / 3$ bagian adonan pada daun pisang, ratakan. Taruh bandeng di atasnya lalu tutup permukaan bandeng dengan sisa adonan. 
10. Bungkus bandeng dan sematkan tusuk gigi pada ujung-ujungnya. Bakar bandeng di atas bara api hingga matang. Angkat, sajikan segera.

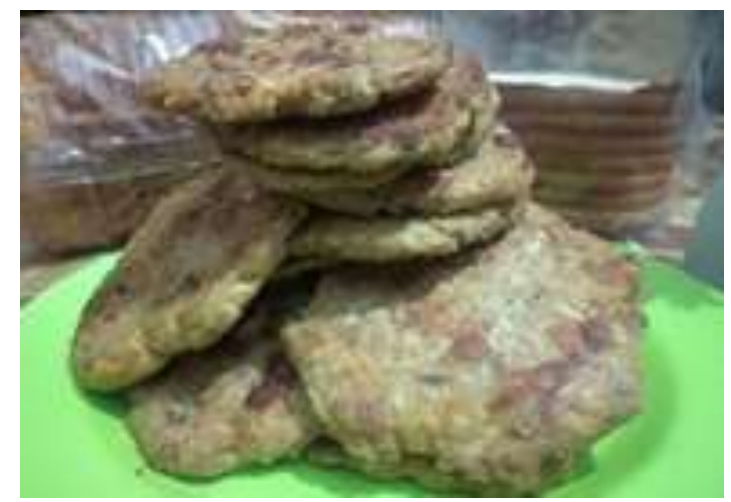

gambar 5. Daging Burger Bandeng

Saat ini banyak makanan yang terbuat dari bahan baku olahan ikan, membuat banyak pengusaha makanan membuat aneka jenis makanan seperti halnya hamburger dengan isian ikan bandeng yang banyak disukai oleh para konsumen. Burger ini ialah makanan yang berupa roti serta memiliki bentuk bundar yang diiris menjadi dua bagian. Burger ini sangat identik dengan bagian tengah yang diberi isian aneka jenis bahan seperti daging, sayuran misalnya selada, bawang bombay, dan tomat. Burger dari bahan ikan bandeng ini menjadi makanan siap saji yang nikmat dan banyak disukai masyarakat.

\section{Bahan-Bahan:}

- 1 ekor bandeng

- 1 sdm bawang putih bubuk

- $\quad 3 \mathrm{sdm}$ tepung roti

- 1 sdt merica bubuk

- $\quad 1 / 2$ bawang bombay cincang

- Sejumput oregano kering

- 1 butir telur ayam kampong

- $\quad 1 \mathrm{sdm}$ minyak goreng

- $\quad 1$ sdt kaldu jamur (opsional)

\section{Cara Pembuatan:}

1. Campur semua bahan jadi satu. Aduk rata. Tes rasa dengan menggoreng sedikit adonan di teflon dengan sedikit minyak.

2. Bulatkan dengan menggunakan ring. Dengan ketebalan sekitar $1 / 2 \mathrm{~cm}$ kurleb. Bungkus dengan plastik wrap. Simpan di kulkas/freezer jika akan digunakan nanti. 


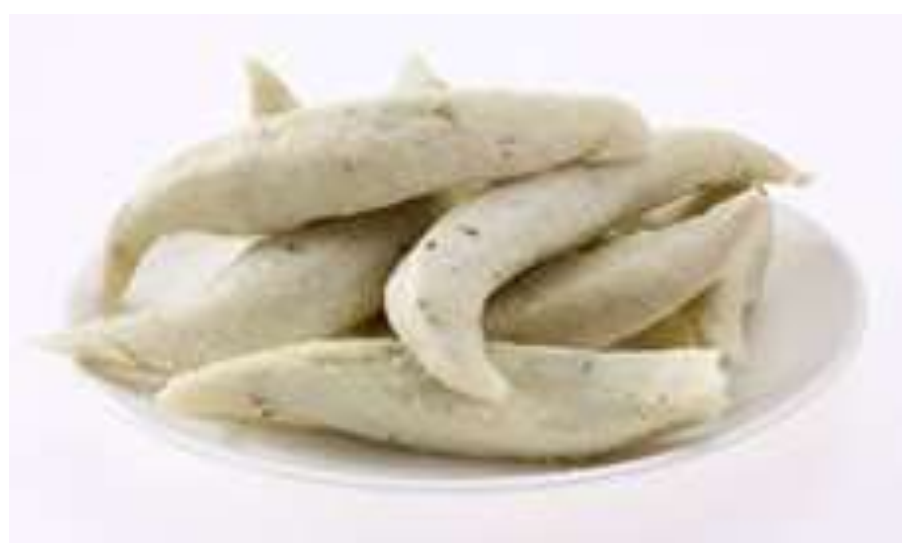

Gambar 6. Otak-Otak Bandeng

Otak-otak bandeng merupakan produk dari daging ikan bandeng yang dibuat dari campuran daging bandeng lumat, tapioka dan bumbu-bumbu seperti gula, garam, santan kental, bawang putih, bawang merah, lada dilakukan proses penggorengan.

\section{Bahan-Bahan:}

- 1 ekor bandeng kurleb $700 \mathrm{~g}$

- 2 siung bawang putih

- $1 / 2$ sdt merica bubuk

- Garam

- $1 / 2$ sachet royco ayam

- 3 sdm tepung terigu

- 2 sdm tepung kanji

- 1 butir telur ayam

- Secukupnya daun pisang (utk bungkus)

\section{Cara Pembuatan:}

1. Bersihkan sisik dan isi perut dan kepala ikan bandeng (belah samping), kucuri dengan jeruk nipis agar mengurangi bau amis cuci sampai bersih

2. Tarik ikan bandeng smpe bunyi krek, kemudian gepuk2 ikan bandeng smpai lembek utk memisahkan daging dengan duri ikan

3. Pisahkan daging ikan bandeng yang sudah lembek karna digepuk tadi

4. Blender daging bandeng, bumbu halus, bawang putih, lada, garam

5. Campur daging ikan yg sudah halus dengan bumbu, tambahkan telur,tepung terigu dan kanji aduk merata tambahkan royco 
6. Tata kulit ikan di atas daun, kulit ikan masih menyatu kepala dan ekor ya, isi dengan adonan daging td sampai penuh, gulung/bungkus dengan daun pisang dengan sematkan lidi kedua sisinya, kukus kurleb 1jam

7. Potong otak-otak bandeng setengah matang (udh dingin dr kukusan) celupkan ke kocokan telur tinggal goreng sampai kuning keemasan.

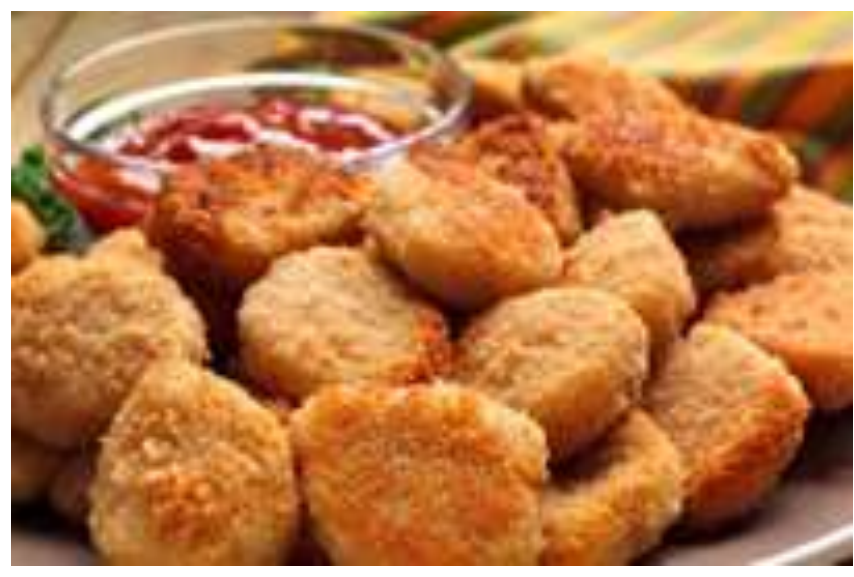

Gambar 7. Nugget Bandeng

Nugget Bandeng adalah olahan daging ikan Bandeng yang dicampur dengan sedikit tepung dan telur sebagai bahan dasar. Jenis olahan ini dapat dinikmati dalam jangka panjang karena penyimpanan sebelum dikonsumsi dalam suasana beku.

\section{Bahan-Bahan:}

- 500 gr ikan bandeng yang sudah dibersihkan dari duri dan kulit

- 2 sendok makan Tepung Tapioka

- 3 butir Telur ayam

- $750 \mathrm{ml}$ Minyak goreng, untuk menggoreng

- $\quad$ (Bumbu Nugget Bandeng)

- 4 siung Bawang putih, cincang halus

- Bawang bombay cincang halus

- 1 batang Bawang perai, iris tipis

- 2 sendok makan Kecap asin

- Garam secukupnya

- Gula pasir secukupnya

- 1 sendok teh Merica bubuk

- 1 sendok teh Minyak wijen

- 1 butir Telur ayam, kocok

- 100 gram Tepung terigu protein sedang, 
- 100 gram Tepung pangko/panir

\section{Cara Pembuatan:}

1. Panaskan minyak dalam wajan, tumis bawang putih dan bawang bombay hingga harum. kemudian Angkat.

2. Campur bahan-bahan dan bumbu yang lain, aduk rata. Tuang adonan kedalam loyang kotak berukuran $15 \times 15 \times 3 \mathrm{~cm}$ yang dialasi plastik. lalu Ratakan.

3. Selanjutnya Panaskan panci pengukus, kukus adonan hingga matang kurang lebih 15 menit. Angkat dan dinginkan, potong balok.

4. Gulingkan adonan dalam terigu hingga rata. Celup dalam sisa telur yang dikocok, angkat. Gulingkan dalam tepung pangko/panir.

5. Panaskan minyak, goreng adonan hingga kuning kecokelatan. Angkat dan tiriskan. Sajikan Nugget Ikan Bandeng hangat-hangat.

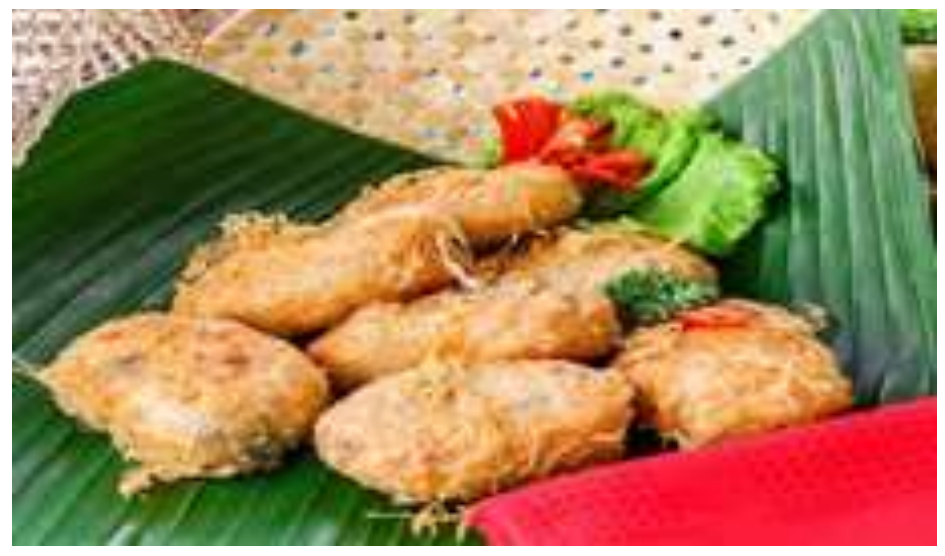

Gambar 8. Perkedel Bandeng

Perkedel bandeng adalah hidangan yang terbuat dari kentang yang ditumbuk, lalu dicampur dengan daging ikan bandeng yang telah dihaluskan kemudian ditambahkan dengan bumbu dan irisan daun bawang serta seledri. Kemudian dicelupkan dalam kocokan telur dan kemudian digoreng.

\section{Bahan-Bahan:}

- 2 ekor ikan bandeng tanpa duri

- 100 gr udang kupas (cincang)

- 1 butir telur ayam

- 2 bungkus Kobe Tepung Bakwan Kress (75 gr)

- 2buah cabai merah (buang biji dan iris tipis)

- 1 batang daun bawang (iris halus) 
- $1 / 2$ sendok teh merica

- $300 \mathrm{ml}$ minyak goreng

- 2 butir telur ayam (sebagai balutan)

\section{Cara Pembuatan:}

1. Campurkan semua bahan kecuali minyak goreng dan telur untuk balutan.

2. Aduk hingga rata dan bentuk adonan menjadi oval.

3. Kocok telur. Celupkan adonan ke dalam kocokan telur hingga rata.

4. Goreng dalam minyak panas hingga matang dan berwarna kuning kecoklatan.

5. Angkat dan sajikan selagi hangat.

\section{Sosialisasi Edukasi Masyarakat}

Menjalankan program partisipatif, dengan cara mengadakan suatu kegiatan Webinar Edukasi yang membahas mengenai Revitalisasi Emping Melinjo dan Sate Bandeng Berbasis Local Food Diversification Guna Meningkatkan Perekonomian Masyarakat Di Kota Serang Provinsi Banten.

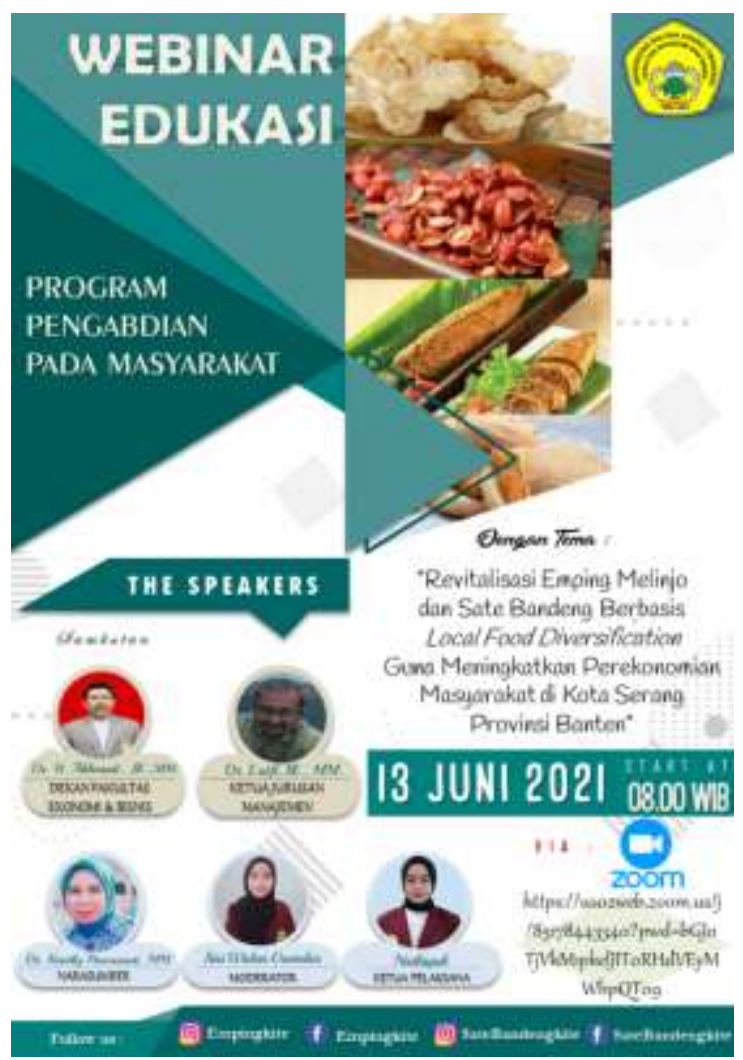

Gambar 9. Webinar Revitalisasi Emping Melinjo dan Sate Bandeng 


\section{KESIMPULAN}

Pembelajaran Pemberdayaan Masyarakat (PPM) adalah Suatu kegiatan yang melibatkan mahasiswa untuk turun dan mengabdi kepada masyarakat sebagai penyempurnaan proses belajar mahasiswa. Bentuk dari perwujudan rasa tanggung jawab mahasiswa untuk melaksanakan salah satu Tri Dharma perguruan tinggi. Kegiatan pembelajaran pemberdayaan masyarakat (PPM) ini menjadikan mahasiswa lebih tanggap dan peka terhadap permasalahan yang ada dalam kehidupan masyarakat. Dengan adanyanya pembelajaran pemberdayaan masyarakat mahasiswa diharapkan dapat menyelesaikan segala permasalahan yang ada dan mampu menerapkan ilmi-ilmu yang telah diperolehnya di bangku kuliah, dan dipusatkan pada kehidupan masyarakat kearah lebih maju dalam sekejap, tetapi dengan kehadiran mahasiswa peserta PPM ternyata dapat merubah pola pikir masyarakat menuju kearah yang lebih baik. Mahasiswa harus mampu menjadi penggerak pembangunan yang mampu membawa perubahan dan kemajuan di segala aspek kehidupan. Emping Melinjo dan Sate bandeng merupakan asli dari Kota Serang. Setelah mahasiswa melakukan pembelajaran ternyata Emping Melinjo dan sate bandeng dapat meningkatkan perekonomian masyarakat sekitar yang dapat diolah berbagai macam makanan Emping Melinjo contohnya Emping cookies, emping karamel, stik Emping Melinjo, dan keripik kulit melinjo sedangkan macam-macam makanan dari sate bandeng contohnya Daging burger bandeng, otakotak bandeng, nugget bandeng, dan perkedel bandeng.

\section{TANDA TERIMAKASIH}

Tanda terimakasih atas terselenggaranya PPM ini dberikan kepada:

1. Rektor Untirta, Prof. Dr. Fatah Sulaiman, ST., MT

2. Ketua LPPM Untirta, Dr. Ir. Rusmana, M.Si

3. Dekan FEB Untirta, Dr. Akhmadi, SE., MM

4. Wakil Dekan Bidang Akademik FEB Untirta, Dr. Indra Suhendar, SE., M.Si

5. Ketua Jurusan Manajemen, Dr. Lufti, SE., MM

6. Pimpinan UMKM Emping Melinjo, Bapak Jawiulloh, Ds. Kubang, Kel. Cilowong, Kecamatan Taktakan Kecamatan Taktakan, Kota Serang

7. Pimpinan UMKM Sate Bandeng Ibu Aliyah, Kecamatan Serang, Kota Serang

8. Mahasiswa Jurusan Manajemen FEB Untirta, khususnya semester 6.

\section{DAFTAR PUSTAKA}

Enginering System. (2017) Industri Emping Melinjo dan Kendala yang Dihadapinya. Website,http://engineering diakses pada tanggal 2 April 2020 
Gozali, Thomas., dkk. (2017). Peningkatan Daya Tahan Simpan "Sate Bandeng" (Chanoschanos) Dengan Cara Penyimpanan Dingin Dan Pembekuan. Infomatek, 6, 51-66.

Ika Puji Utami, Adi Suyatno, Imelda Imelda. (2020). “Analisis Keuntungan Usaha Industri Emping Melinjo Skala Rumah Tangga Di Kelurahan Sungai Jawi Kecamatan Pontianak Kota." Jurnal Sains Mahasiswa Pertanian Vol IV No 2. Online: http://jurnal.untan.ac.id/index.php/jspp

Masyhuri. (2020). "Pengembangan Agroindustri Melalui Penelitian Dan Pengembangan Produk Yang Intensif Dan Berkesinambungan.” Dalam Jurnal AgroEkonomi Vol VII/ No 1 Juni / 2000. Jurusan Sosial Ekonomi Pertanian.

Meutiaa, dkk. (2018). Keputusan Dan Tingkat Kepuasan Konsumen Dalam Memilih Aneka Sate Bandeng Di Propinsi Banten. Prosiding Forum Komunikasi Perguruan Tinggi Pertanian Indonesia (FKPTPI), 789-805.

Nur, Muhammad. (2017). Pengaruh Pengemasan, Jenis Bahan Pengemas, Dan Lama Penyimpanan Terhadap Sifat Kimia, Mikrobiologi, Dan Organoleptik Sate Bandeng. Jurnal Teknologi Industri dan Hasil Pertanian, 14, 1-11.

Putri, Ika Solehati. dkk. (2020). Pengembangan Produk Olahan Ikan Bandeng Di Desa Sukamah. Jasintek, 2, 1-7.

Prijana. Yanto, Andri. Koswara, Iwan. Komariah, Neneng. (2017). Workshop Pemasaran Online Produk Industri Kereatif Melalui Media Sosial Di Kecamatan Cikalong Kabupaten Tasikmalaya. Jurnal Aplikasi Ipteks untuk Masyarakat. Vol. 6, No. 3, 160 - 162.

Stiawati, Titi. Dewi, Shanty Kartika. (2019). Pembinaan Keterampilan Hiasan Dan Modelhantaran Pernikahan Di Kota Cilegon. Jurnal Pengabdian Dinamika. Edisi 6 Volume 1.

Ulhaq. Muhammad Dhiya. (2020). PschyoAmity; Psyhological Assistance and Amiable-based Activity bagi narapidana Lapas Wirogunan Yogyakarta. Proposal PKM Pengabdian Masyarakat. Fakultas Ilmu Budaya. Universitas Gadjah Mada.

Winangsih, Rahmi., dkk. (2019). Membangun Kemandirian Pangan Melalui Manajemen Komunikasi Pemasaran Sate Bandeng Sebagai Produk Unggulan Kota Serang. Jurnal Pengabdian Masyarakat Ipteks, 5, 105-114.

Questibrilia, Bivisyani. (2020). Manfaat dari Viral Marketing untuk Bisnis Website,https://www.jojonomic.com/blog/viral-marketing/ diakses pada tanggal 2 April 2020. 